\title{
UNEMPLOYMENT RATE AND WAGE GROWTH IN BRAZIL: EVIDENCE FROM A MARKOV-SWITCHING MODEL
}

\author{
Wellington Charles Lacerda Nobrega* \\ Cássio da Nóbrega Besarria ${ }^{\dagger}$ \\ Felipe Araujo de Oliveira ${ }^{\ddagger}$
}

\begin{abstract}
This paper has the purpose to investigate the relationship between unemployment rate and wage growth for the Brazilian economy from 2000 to 2016, by means of a Markov-switching regression model. The empirical approach is based on the New-Keynesian Phillips Curve developed by Galí (2011). The estimation results suggest the existence of two welldefined regimes, one characterized by the non-validation of the Phillips Curve, while in the other the trade-off between unemployment and wage inflation is validated, with the economic cycle being a key factor in regime switching.
\end{abstract}

Keywords: unemployment, wage, Markov switching, NAIRU, Phillips curve.

\section{Resumo}

Este artigo tem o propósito de investigar a relação entre a taxa de desemprego e o crescimento dos salários na economia brasileira entre 2000 e 2016, através de um modelo de regressão com mudança markoviana. A estratégia empírica é baseada na curva de Phillips Novo-Keynesiana desenvolvida por Galí (2011). Os resultados da estimação sugerem a existência de dois regimes bem definidos, um caracterizado pela não validação da curva de Phillips, enquanto no outro o trade-off entre desemprego e inflação nos salários é validado, sendo o ciclo econômico um fator chave na transição entre regimes.

Palavras-chave: desemprego, salários, Markov switching, NAIRU, curva de Phillips.

JEL classification: C24, E24, E32.

DOI: ht tp://dx.doi .org/10.11606/1980-5330/ea151926

\footnotetext{
${ }^{*} \mathrm{PhD}$ in Applied Economics, Federal University of Paraíba. E-mail: wellington_charles@hotmail.com

${ }^{\dagger} \mathrm{PhD}$ in Applied Economics, Federal University of Paraíba. E-mail: cassiodanobrega@yahoo.com.br

‡ Federal University of Paraíba and Risk Management Analyst at B3. Email:felipe.8.araujo@gmail.com
} 


\section{Introduction}

The unemployment rate is one of the most cited variables in macroeconomic discussion. The main reason is the fact that this variable directly reflects formal labor conjecture and indirectly provides an overview of families welfare. In this context, the raising interest of policy makers in this variable is notoriously higher in recession periods, when every objective converges towards the reduction of unemployment and the maintenance (or recovery) of sustainable economic growth.

In a seminal work, Phillips (1958) described what became one of the most famous relations in economic scientific literature: the inverse relationship between unemployment rate and nominal wage growth, widely known as the Phillips curve. A given high unemployment rate, requires a lower nominal wage growth. In other words, there is a trade-off between wage inflation and unemployment. Questions related to the stability of this relationship emerged over the last decades, for instance, Friedman (1977) argues that the Phillips curve would be negatively inclined in the short-run while it would be vertical in the long-run, in other words, the above mentioned trade-off would be temporary instead of permanent.

Hence, a better understanding of this relationship dynamics is of great importance to policy makers. Moreover, the existence of a purely linear relationship among the variables suggests that policy actions taken in different periods would have symmetric effect on the labor market, given the invariability of this relationship over time. However, in case of a nonlinear dependence, policy actions taken in different moments would have asymmetric effects on the labor market, thereby being amplified or mitigated.

In Brazil, the recent economic crisis strongly affected the unemployment trajectory. The variable exhibited a reversal in trend, achieving a peak of $13.7 \%^{1}$ in the first quarter of 2013 , representing a contingent of 13 millions of unemployed people. Furthermore, some characteristics of the Brazilian labor market related to wage frictions feed the belief in an asymmetric response of wage given the unemployment rate changes. Thus, questions arise about the effects of economic policy actions on the labor market in Brazil: was there a time varying relationship between unemployment rate and wage growth rate in Brazil? In other words, are there non-linearities in the Brazilian Phillips curve?

This paper is related to other studies that sought to investigate the relationship between unemployment and price inflation in Brazil, as Mendonça \& Santos (2006), Oliveira \& Feijó (2015), Aragon et al. (2016), Triches \& Feijó (2017) and Oliveira \& Feijó (2017). However, the present paper is based on the original relationship proposed by Phillips (1958), thereby directing our research to the interaction between unemployment rate and wage growth, as Bacha \& Lima (2004), Campos et al. (2010) e Mendonça et al. (2012). In this sense, both Galí (2011) and Donayre \& Panovska (2016) argues that wage inflation has a better fit, relative to price inflation, on labor market dynamics.

The empirical model used in this paper is based on the theoretical framework developed by Galí (2011). This author, aiming to investigate the determinants of unemployment slow recovery in the USA in the aftermath of

\footnotetext{
${ }^{1}$ According to Pesquisa Nacional por Amostra de Domicílios contínua (PNAD) data, provided by Instituto Brasileiro de Geografia e Estatística (IBGE).
} 
the economic crisis, develops a New-Keynesian model allowing for price and wage stickiness in which the unemployment ${ }^{2}$ is explicitly introduced. From there, he derives a New-Keynesian Phillips curve that relates wage growth and unemployment rate, named New-Keynesian Wage Phillips Curve (NKWPC).

In this research, the purpose is to investigate the relationship between wage growth and unemployment rate in Brazil. Specifically, one sought to estimate the Phillips curve developed by Gali (2011) in the period from 2000 to 2016. To achieve this goal, it was used a Markov-switching regression model (MSR). Following that, one also sought to investigate the existence of nonlinearities in the relationship between wage and unemployment, in order to evaluate possible asymmetries as well as to investigate a possible cause for the high unemployment in the recent years.

The main findings of the Phillips curve estimate suggests an existence of two well-defined regimes. The first regime is characterized by the nonvalidation of Phillips (1958) relationship, while under the other regime, wage inflation and unemployment rate trade-off is validated, being possible to associate the economic cycle as a fundamental factor in regime transition. This is an interesting result in that it associates previously performed research when identifying Phillips relation validation periods, as did Bacha \& Lima (2004) and Campos et al. (2010), interleaved by periods of non-validation of this relation, according to Schwartzman (2006), Mendonça et al. (2012), Sachsida et al. (2009), among others. Furthermore, this result is in line with other studies that used Markov switching model approach, such as did Oliveira \& Feijó (2015) who, on estimating a Hybrid New-Keynesian Phillips Curve, identified antagonistic Markov regimes with similar behavior to that found in the present research.

Thus, this article has six (6) sections, including this short introduction. Section 2 presents a brief conjuncture about unemployment rate, wage and gross domestic product (GDP) in Brazil and some selected economies. In 3, it is described the Phillips curve specification. Section 4 shows the econometric procedures performed in the present research, presenting the Markov switching regression model in subsection 4.1 , while subsection 4.2 describes the data source and the initial treatment carried out on the time series. Finally, subsection 4.3 shows NAIRU estimation procedures. Section 5 discusses the main results. Section 6 presents the concluding remarks. In addition, there are appendixes Appendix A and Appendix B.

\section{Conjuncture of the Unemployment, Wage and Output}

This section analyzes the recent evolution of Brazil's economy and presents information about the main determinants of economic activity, matching these indicators with other selected emerging economies. The period that followed the year of 2013 was marked by a strong rise on commodities prices and Brazil was one of the countries that benefited from this cycle ${ }^{3}$.

\footnotetext{
${ }^{2}$ Characterized with a definition similar to that used by institutions responsible for unemployment statistics, i.e.: individuals who wish to work but can not find a job.

${ }^{3}$ An immediate effect of rising commodities prices, as pointed out by Garton \& Others (2008) to the Australian case, is the domestic relative prices shift, inducing the reallocation of resources among sectors and real income boosting, resulting in an aggregate demand stimulus - not necessarily symmetrically among sectors.
} 
This improvement in the international scenario had a positive effect on Brazil's service sector, specifically, focused on labor intensive sectors as construction, commerce and financial mediation. This fact provided a higher job creation (generally lower qualified) and led to a rise in wages. By looking at some data about unemployment in the Brazilian economy, one observes a decreasing trend that goes from $13.7 \%$ in 2003 to $6.8 \%$ in 2014 .

However, the recent economic crisis reversed the trend towards an increase of this indicator, thereby registering a strong acceleration of the unemployment rate to $12.8 \%$ in 2017 , representing a contingent of approximately 13 millions of unemployed people. The Table 1 shows the unemployment rate evolution in Brazil and some selected emerging economies along with the G7.

Table 1: Annual unemployment rate (\%) for selected countries along with G7

\begin{tabular}{rrrrrrrrr}
\hline Year & Brazil & Chile & China & Colombia & Paraguay & Russia & Uruguay & G7 \\
\hline 2000 & 13.9 & 9.7 & 3.1 & 13.3 & 7.3 & 10.6 & 13.4 & 5.6 \\
2001 & 12.5 & 9.9 & 3.6 & 15.0 & 7.6 & 9.0 & 15.2 & 5.9 \\
2002 & 13.0 & 9.8 & 4.0 & 15.6 & 10.8 & 8.0 & 16.8 & 6.4 \\
2003 & 13.7 & 9.5 & 4.3 & 14.1 & 8.1 & 8.2 & 17.2 & 6.6 \\
2004 & 12.9 & 10.0 & 4.2 & 13.7 & 7.3 & 7.7 & 13.3 & 6.3 \\
2005 & 11.4 & 9.3 & 4.2 & 11.8 & 5.8 & 7.2 & 12.1 & 6.2 \\
2006 & 11.5 & 8.0 & 4.1 & 12.0 & 6.7 & 7.1 & 10.8 & 5.7 \\
2007 & 10.9 & 7.0 & 4.0 & 11.2 & 5.6 & 6.0 & 9.4 & 5.4 \\
2008 & 9.4 & 7.8 & 4.2 & 11.3 & 5.7 & 6.2 & 7.9 & 5.8 \\
2009 & 9.7 & 10.8 & 4.3 & 12.0 & 6.4 & 8.2 & 7.8 & 8.0 \\
2010 & 8.5 & 8.2 & 4.1 & 11.8 & 5.7 & 7.4 & 7.0 & 8.1 \\
2011 & 7.8 & 7.1 & 4.1 & 10.8 & 5.6 & 6.5 & 6.4 & 7.6 \\
2012 & 7.4 & 6.4 & 4.1 & 10.4 & 4.6 & 5.5 & 6.3 & 7.4 \\
2013 & 7.2 & 5.9 & 4.1 & 9.7 & 5.0 & 5.5 & 6.5 & 7.1 \\
2014 & 6.8 & 6.4 & 4.1 & 9.1 & 6.0 & 5.2 & 6.6 & 6.4 \\
2015 & 8.3 & 6.2 & 4.1 & 8.9 & 5.4 & 5.6 & 7.5 & 5.8 \\
2016 & 11.3 & 6.5 & 4.0 & 9.2 & 6.0 & 5.5 & 7.9 & 5.4 \\
2017 & 12.8 & 6.7 & 3.9 & 9.3 & 5.7 & 5.2 & 7.4 & 5.0 \\
\hline
\end{tabular}

Source: Elaborated from Monetary International Fund (IMF) data.

[1] Note: The G7 is composed by Germany, Canada, The United States, France, Italy, Japan and The United Kingdom.

The recent bad performance (2014-2017) experienced by the Brazilian economy contrasts with the recent results of most part of emerging economies as well as advanced economies. It is possible to observe that emerging countries such as China, Russia, Paraguay and Colombia registered an unemployment reduction, while both Chile and Uruguay presented a slight increase, however, the unemployment rate of the latter are stable. In the case of advanced economies that composes the G7, those have registered a reduction in the unemployment rate, of which one can highlighting the United States which registered only $3.9 \%$ in 2017.

1 (a) presents the evolution of the relationship between unemployment and wage in Brazil, while (b) shows a scatter-plot of the same relation, with a trend line estimated through ordinary least squares (OLS). The series behavior in 1 (a) suggests a possible negative relationship between unemployment and wage, a first empirical evidence of this association is given by Pearson's 
correlation coefficient, with a value of -0.76, indicating the existence of a negative correlation (evidenced by a coefficient sign) of moderate intensity among the variables; furthermore, this association is reinforced when the right side of 1 (b) is analyzed, where the estimated trend line has a negative inclination. These first indicators are according to the empirical relation proposed by Phillips (1958), that negatively relates unemployment and wage.

Figure 1: Relationship between unemployment and wage series in Brazil
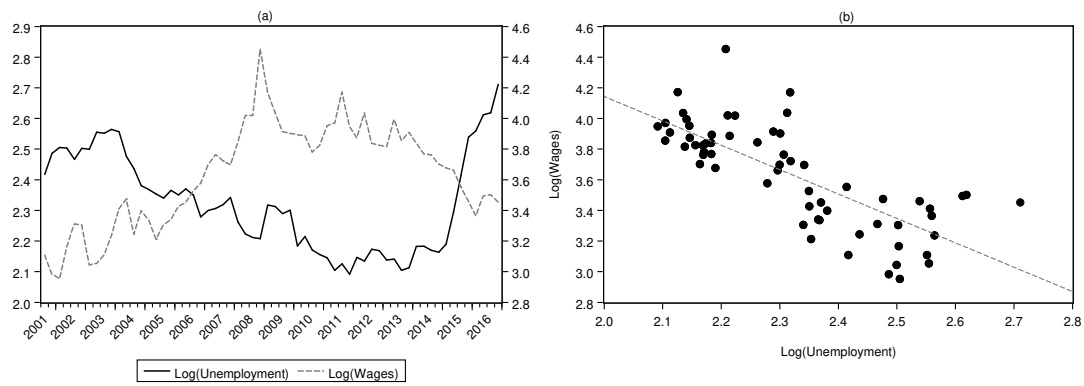

Source: Elaborated from MTE and BACEN data.

[1] Note: Logarithmic series.

Given this contextualization of the unemployment in Brazil, we set out to discuss the behavior of gross domestic product growth (GDP). Looking at the GDP growth data from 2003 to 2013, it is possible to point out that Brazil experienced a strong growth of this indicator, reaching its peak in 2010 when it registered $7.5 \%$. However, the economic performance reversal began to present its signs in 2014 year when the GDP growth started to decelerate, achieving for two consecutive years (2015 and 2016) a negative growth, which was timidly reverted to $1.0 \%$ in 2017 .

One can observe in Table Table 2 that the economic activity deceleration was not an isolated fact limited to the Brazilian economy. Emerging economies such as Chile, Colombia and Russia also presented a reduction in their GDP growth rate over the last years. On the other hand, China's product growth showed up relatively stable around $7.0 \%$ per year. Given the importance of both variables in the international macroeconomic scenario, the 2 presents the Brazilian relation between unemployment rates and real GDP from 2002 to 2017.

3 (a) suggests a possible negative association between both economic and unemployment cycles, according to the Okun's law proposal. This association is reinforced by 3 (b), in which the estimated trend line shows a negative relation between unemployment and GDP. In other words, growth (retraction) periods are associated to labor market heating, reflecting in an elevation (reduction) in the number of employed people and consequently a reduction (rise) in the unemployment rate.

Besides that, 3 (a) presents the annual evolution of the average income, the minimum wage and the total factor productivity (TFP), while (b) shows a comparative of the Brazilian TFP against selected countries. Generally, the income yield starts to present real gains in 2005, reaching its peak also by 2014. Furthermore, the minimum wage had real gains, which were even larger in the analyzed period. According to Bonelli \& Veloso (2014), the informality 
Table 2: Annual GDP growth (\%) for selected countries along with G7

\begin{tabular}{rrrrrrrrr}
\hline Ano & Brasil & Chile & China & Colombia & Paraguai & Russia & Uruguai & G7 \\
\hline 2000 & 4.4 & 5.3 & 8.4 & 2.9 & -2.3 & 10.0 & -1.8 & 3.8 \\
2001 & 1.4 & 3.3 & 8.3 & 1.7 & -0.8 & 5.1 & -3.5 & 1.3 \\
2002 & 3.1 & 3.1 & 9.1 & 2.5 & 0.0 & 4.7 & -7.1 & 1.3 \\
2003 & 1.1 & 4.1 & 10.0 & 3.9 & 4.3 & 7.3 & 2.3 & 1.9 \\
2004 & 5.8 & 7.2 & 10.1 & 5.3 & 4.1 & 7.2 & 4.6 & 2.9 \\
2005 & 3.2 & 5.7 & 11.3 & 4.7 & 2.1 & 6.4 & 6.8 & 2.5 \\
2006 & 4.0 & 6.3 & 12.7 & 6.7 & 4.8 & 8.2 & 4.1 & 2.5 \\
2007 & 6.1 & 4.9 & 14.2 & 6.9 & 5.4 & 8.5 & 6.5 & 2.0 \\
2008 & 5.1 & 3.6 & 9.6 & 3.5 & 6.4 & 5.2 & 7.2 & -0.3 \\
2009 & -0.1 & -1.6 & 9.2 & 1.7 & -4.0 & -7.8 & 4.2 & -3.8 \\
2010 & 7.5 & 5.8 & 10.6 & 4.0 & 13.1 & 4.5 & 7.8 & 2.8 \\
2011 & 4.0 & 6.1 & 9.5 & 6.6 & 4.3 & 5.1 & 5.2 & 1.6 \\
2012 & 1.9 & 5.3 & 7.9 & 4.0 & -1.2 & 3.7 & 3.5 & 1.4 \\
2013 & 3.0 & 4.1 & 7.8 & 4.9 & 14.0 & 1.8 & 4.6 & 1.4 \\
2014 & 0.5 & 1.8 & 7.3 & 4.4 & 4.7 & 0.7 & 3.2 & 2.0 \\
2015 & -3.5 & 2.3 & 6.9 & 3.1 & 3.0 & -2.5 & 0.4 & 2.1 \\
2016 & -3.5 & 1.3 & 6.7 & 2.0 & 4.0 & -0.2 & 1.5 & 1.4 \\
2017 & 1.0 & 1.5 & 6.9 & 1.8 & 4.3 & 1.5 & 3.1 & 2.1 \\
\hline
\end{tabular}

Source: Elaborated from Monetary International Fund (IMF) data.

[1] Note: The G7 is composed by Germany, Canada, The United States, France, Italy, Japan and The United Kingdom.

Figure 2: Relationship between both unemployment and real GDP cycle
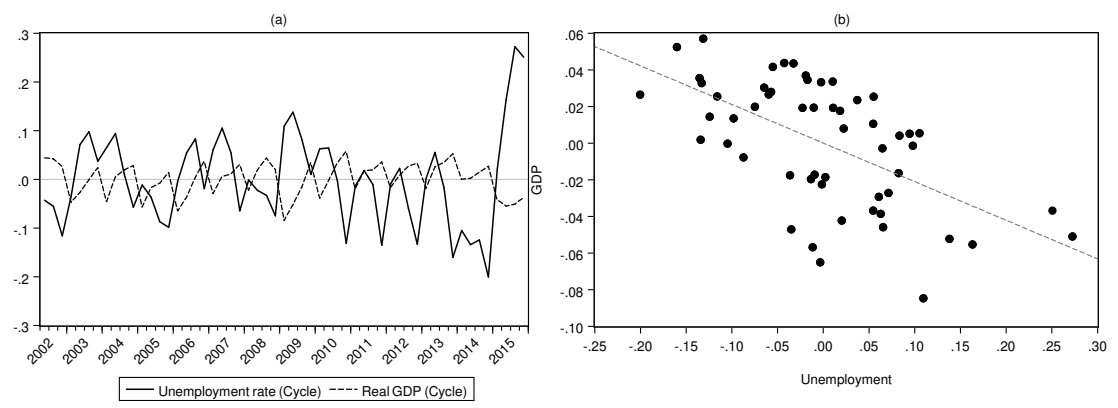

Source: Elaborated from IBGE and BACEN data.

[1] Note: Logarithmized series, then, trend extracted by means of Hoddrick-Prescott filter. 
rate reduction was also relevant in the rise of occupied people. In other words, with the rise in the average income above the economy productivity, there was a rise in labor supply.

Figure 3: Average income per employed and occupied, minimum wage, TFP (\% a.y) and comparative of the Brazilian TFP against selected countries
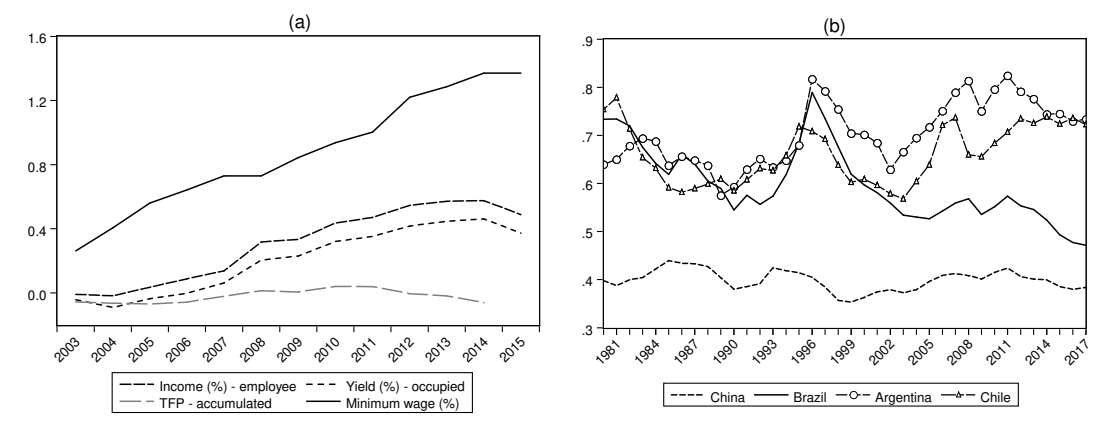

Source: Elaborated from IPEADATA, IBGE and PWT (9.0 and 8.1) data.

Despite wage growth, the productivity stagnated in the analyzed period, as one can observe by the TFP behavior, also in the 3 (a). This mismatch between productivity and the fall of unemployment in Brazil suggests that the economy was at full employment, which requires higher real wages in order to attract labor. This scenario becomes even more evident in 2012, when the TFP decreases and yields accelerate, generating a rise in the unitary cost and inflationary pressures. Still in the 3 (b), it is possible to note that Brazilian TFP is situated below the productivity of emerging economies such as Argentina and China.

In short, without productivity gains, any stimulus to aggregate demand is turned into inflationary pressure ${ }^{4}$. Intuitively, it might exist no trade-off between unemployment and the rate of wage inflation, even in the short-run. A decreasing productivity may generate wage-push inflation ${ }^{5}$, invalidating the classical Phillips Curve relationship and, consequently, triggering wrong decisions by policy makers. In this scenario, choosing a mix of monetary and fiscal policies to expand demand can possibly generate a higher inflation without reaching higher levels of employment and GPD as well. This scenario itself highlights the relevance of this research.

\section{New-Keynesian Wage Phillips Curve (NKWPC)}

In order to investigate the existing relation between wage and unemployment, this paper used the theoretical framework developed by Gali (2011) which is an extension of the standard sticky wage model developed by Erceg et al.

\footnotetext{
${ }^{4}$ This point is corroborated by Bonelli \& Veloso (2014). These authors suggest that to maintain the inflation in the target, it would be necessary a nominal wages rising at $4.5 \%$ per year while it grows at $8 \%$ per year at full employment.

${ }^{5}$ In order to make this point clear, imagine the counter-factual scenario: productivity grows as fast as real wage rate and, as a result there is no effect in the equilibrium price and on the unemployment level. The net effect is a higher aggregate supply in the economy, with room to aggregate demand stimulus without inflationary pressures.
} 
(2000). Through a New-Keynesian framework and admitting rigidity as proposed by Calvo (1983) in the relations that determine wage, Erceg et al. (2000) derived the wage inflation equation, expressed as follow

$$
\pi_{t}^{w}=\beta \mathbb{E}_{t}\left(\pi_{t+1}^{w}\right)-\lambda_{w}\left(\mu_{t}^{w}-\mu^{w}\right)
$$

where $\pi_{t}^{w}=\left(w_{t}-w_{t-1}\right)$ is the wage inflation, $\mu_{t}^{w}$ is the average wage markup and $\mathbb{E}[\cdot]$ is the expectations operator.

Gali (2011) replaced the wage markup with the unemployment rate by making some assumptions about the household's decisions regarding the labor supply. In short, the representative household aims to maximize its intertemporal utility, which is assumed to be indivisible, over its lifetime horizon, subject to its budget constraint. The household's utility is given in the a standard CRRA function, as follows:

$$
\mathbb{U}\left(C_{t}, N_{t}\right)=\log C_{t}-\frac{N^{1+\varphi}}{1+\varphi}
$$

where $C_{t}$ denotes the household consumption level and $N_{t}$ is the labor supply in $t$. Under the conditions mentioned above, the optimal labor supply choice in a log-linearized form is given by:

$$
w_{t}-p_{t}=c_{t}+\varphi l_{t}
$$

where the lower case letters represent the log-deviation form of the variables. Intuitively, Equation (3) shows that labor supply decisions are based on the level of real wage and disutility of labor supply.

By defining the log-linear form of unemployment rate as $u_{t}=\left(n_{t}-l_{t}\right)$, Galí (2011) found the following relationship between wage markup and unemployment rate:

$$
\mu^{w}=\varphi u_{t}
$$

Then, based on (4), the natural rate of unemployment $\left(u^{n}\right)$ - which is defined as the unemployment rate prevailing under flexible wages - is a simple linear function of the wage markup:

$$
u^{n}=\frac{1}{\varphi} \bar{\mu}^{w}
$$

Finally, by replacing Equations (4) and (5) into Equation (1), the basic form of the New-Keynesian Wage Phillips Curve is found:

$$
\pi_{t}^{w}=\beta \mathbb{E}_{t}\left(\pi_{t+1}^{w}\right)-\lambda_{w} \varphi\left(u_{t}-u^{n}\right)
$$

Equation (6) shows that wage inflation is inversely related to unemployment rate as well as the original Phillips Curve which was derived in Phillips (1958) at first. In an alternative specification, Galí (2011) assumes an automatic indexation of price inflation into wage contracts, resulting in the following wage setting rule:

$$
w_{t+k \mid t}=w_{t+k-1 \mid t}=\gamma \bar{\pi}_{t+k-1}^{p}+(1-\gamma) \pi^{p}+g
$$

where $w_{t+k \mid t}$ is the logarithm of the wage in the period $t+k, \bar{\pi}^{p}$ is the price inflation used as indexer, $\pi^{p}$ is the steady state level of the price inflation and 
$g$ is steady state productivity growth rate. Finally, the New-Keynesian Wage Phillips Curve is then given by:

$$
\pi_{t}^{w}=\alpha+\gamma \pi_{t-1}^{p}+\beta \mathbb{E}_{t}\left[\pi_{t+1}^{w}-\gamma \pi_{t}^{p}\right]-\lambda_{w} \varphi\left(u_{t}-u^{n}\right)
$$

where $\alpha=(1-\beta)\left[(1-\gamma) \pi^{p}+g\right]$ and $\alpha, \beta, \gamma, \varphi$ e $\lambda_{w}$ are structural parameters of the model.

Lastly, given that the unemployment rate follows a second-order autoregressive process, $\mathrm{AR}(2)$, according to it's correlogram (as it can be seen in B.1, available in section Appendix A), it can be formally expressed by:

$$
\hat{u}_{t}=\phi_{1} \hat{u}_{t-1}+\phi_{2} \hat{u}_{t-2}+\varepsilon_{t}
$$

where $\hat{u}_{t} \equiv\left(u_{t}-u^{n}\right)$ is the unemployment deviation relative to its natural unemployment rate and $\varepsilon$ is a white noise process. Combining Equation (9) with Equations 7 and 8 yields the wage inflation equation, which is the reduced form of the NKWPC:

$$
\pi_{t}^{w}=\alpha+\gamma \pi_{t-1}^{p}+\psi_{0} \hat{u}_{t}+\psi_{1} \hat{u}_{t-1}
$$

where

$$
\psi_{0}=-\frac{\lambda_{w} \varphi}{1-\beta\left(\phi_{1}+\beta \phi_{2}\right)}, \quad \psi_{1}=-\frac{\lambda_{w} \varphi \beta \phi_{2}}{1-\beta\left(\phi_{1}+\beta \phi_{2}\right)},
$$

Thus, the specification of Equation (10) in order to be estimated follows a Markov-switching process (to be presented in subsection 4.1), which be represented by:

$$
\pi_{t}^{w}=\alpha+\gamma_{s(t)} \pi_{t-1}^{p}+\psi_{0, s(t)} \hat{u}_{t}+\psi_{1, s(t)} \hat{u}_{t-1}+e_{t, s(t)}
$$

in which $e_{t}$ is the disturbance or error term, the subscript $s(t)$ indicates that the estimated parameter is dependent on the regime observed in moment $t$. Finally, it is important to point out that the structural parameters: $\gamma_{s(t)}, \psi_{0, s(t)}, \psi_{1, s(t)}$ e $\sigma_{s(t)}$ are time variant, while $\alpha$ does not vary over the time.

\section{Econometric Procedures}

\subsection{Method}

In order to achieve the objectives proposed in this paper, we estimated a Markov-switching regression model, developed by Hamilton (1989). The main idea of this model is that when the system is subject to a regime shift, there are different regression models associated to a non-observable variable, $s(t)$, which indicates the prevailing regime in period $t$.

Let $\left\{y_{t}\right\}$ denote the vector of interest time series and, defining $M$ as the number of regimes, so that $s(t) \in\{1, \ldots, M\}$, given the regressors $X_{t}, Z_{t}$ and lags of the endogenous variable, the conditional mean of $y_{t}$ in regime $s(t)$ assumes the following dynamic specification:

$$
\mu_{t}(s(t))=X_{t}^{\prime} \beta_{s(t)}+Z_{t}^{\prime} \gamma+\sum_{r=1}^{p} \phi_{s(t)} y_{t-r}
$$


in which $\beta_{s(t)}, \gamma$ and $\phi_{s(t)}$ are the coefficients of the model. Note that both $\beta_{s(t)}$ and $\phi_{s(t)}$ are time variant, while $\gamma$ is not. Lastly, It is assumed that the regression residuals are normally distributed with variance that could be regime dependent. Thus, the model becomes:

$$
y_{t}=\mu_{t}(s(t))+\sigma(s(t)) \varepsilon_{t}
$$

where $s(t) \in\{1, \ldots, M\}$ and $\varepsilon_{t}$ is independent and identically distributed (i.i.d). Furthermore, the standard deviation can vary according to the realized regime, so that: $\sigma(s(t))=\sigma_{s(t)}$.

In this context, a special characteristic of Markov-switching models is related to the fact that the non-observed realizations of regime $s(t) \in\{1,2, \ldots, M\}$ are generated by a time discrete, constituting a stochastic process ruled by Markov chains with discrete states. It is assumed that the regime $s(t)$ is generated by a Markov chain:

$$
\operatorname{Pr}\left(s_{t} \mid\left\{s_{t-j}\right\}_{j=1}^{\infty},\left\{y_{t-j}\right\}_{j=1}^{\infty}\right)=\operatorname{Pr}\left(s_{t} \mid s_{t-1} ; \rho\right)
$$

It is important to point out that, according to Enders (2008), the regime changes are exogenous. Thus, the probability of transition among regimes is expressed by:

$$
P_{i j}=\operatorname{Pr}\left(s_{t+1}=j \mid s_{t}=i\right), \quad \sum_{j=1}^{m}=1 \quad \forall i, j \in\{1,2, \ldots, m\} .
$$

where $P_{i j}$ represents the probability of a shift from regime $i$ to regime $j$ at period $t+1$. The probability of transition can also be represented in matrix form, considering two regimes we have:

$$
T=\left[\begin{array}{cc}
p_{11} & 1-p_{11} \\
1-p_{22} & p_{22}
\end{array}\right]
$$

where $p_{11}$ denotes the probability of remaining in regime 1 when the system is in this regime, in contrast, $1-p_{12}$ represents the possibility of switching to regime 2 if the system is in regime 1.

\subsection{Data}

The inflation series (IPCA and INPC) and the remuneration of employees were extracted from the Brazilian Central Bank (BACEN), on its virtual time series management (SGS) platform. The series used as proxy for the national unemployment rate was obtained from the Ipeadata's virtual platform. The natural unemployment rate (NAIRU) was estimated from the data (procedure explained in detail in subsection 4.3), using the transfer equation, as well as Portugal \& Madalozzo (2000) and Oliveira et al. (2016). The data set is expressed in a quarterly basis covering the period between 2000Q1 and 2016Q4. In Table A. 1 of Appendix Appendix A a brief description about the variables used in this paper is presented. Furthermore, A.1 exposes their temporal trajectory.

Since the original series are in monthly values, it was necessary to perform an interpolation to transform them into quarterly values. For this, a simple average was calculated for the months corresponding to a quarter ${ }^{6}$. In addi-

\footnotetext{
${ }^{6}$ Procedure realized by means of software gretl.
} 
tion, the X-12 ARIMA method was used to perform the seasonal adjustment, when necessary.

In order to verify the presence or not of a unit root in the time series, the unit root tests of Dickey \& Fuller (1979), Phillips \& Perron (1988) and Kwiatkowski et al. (1992) were initially used, and afterwards, considering that the presence of a structural break in the data series may result in spurious results in the conventional unit root tests Perron (1990), the structural break unit root tests of Zivot \& Andrews (1992), Lee \& Strazicich (2003) and Lee \& Strazicich (2013) were also performed.

The results of the tests mentioned above are presented in Table B.1 and Table B.2 of Appendix Appendix B. When related to the conventional unit root tests (Table B.1), these pointed to the stability of the price series, however, for both series of unemployment and wage, the results suggested the presence of a unit root in level, being these stationary in first difference. Regarding the unit root tests allowing for structural changes (Table B.2), there are two significant breaks in the series of unemployment $(\mathrm{U})$ and wage $(\mathrm{W})$.

\subsection{Non-accelerating Inflation Rate of Unemployment (NAIRU) estimation}

The non-accelerating inflation rate of unemployment follows, as methodological approach, an autorregressive transfer equation, according to Enders (2008), because it is a non-observable variable. The articles of Portugal \& Madalozzo (2000) and Oliveira et al. (2016) also used this approach to estimate Brazil's NAIRU for different analysis period.

Intuitively, the transfer equation is represented by a dependent variable $\left(y_{t}\right)$, its lagged values $\left(y_{t-1}\right)$ and also an independent variable $\left(z_{t}\right)$ in current or lagged values. So, the transfer equation can be represented by:

$$
y_{t}=\alpha+\mathrm{A}(\mathrm{L}) y_{t-1}+\mathrm{C}(\mathrm{L}) z_{t}+\mathrm{B}(\mathrm{L}) \varepsilon_{t}
$$

in which, $y_{t}$ and $z_{t}$ are the dependent and independent variable, respectively, in the period $t ; \varepsilon_{t}$ represents the estimation residuals, also in $t$; Lastly, $\mathrm{A}(\mathrm{L}), \mathrm{C}(\mathrm{L})$ e $\mathrm{B}(\mathrm{L})$ are the lag polynomials.

It is important to highlight that it is necessary that all time series be stable in order to apply the transfer equation method Enders (2008). As discussed in Appendix Appendix B, the inflation series (INPC) is level stationary while the unemployment has a unit root. To overcome this problem, we chose to use Hoddrick-Prescott filter ${ }^{7}$, obtaining then, a stable unemployment data series. Finally, the expected inflation series for $t+1$ was calculated, as well as in Portugal \& Madalozzo (2000) and Oliveira et al. (2016), by means of a ARMA model prediction. In this sense, the most accurate prediction model was an $\operatorname{AR}(2)$.

The transfer equation is estimated through a Generalized Method of Moments (GMM) in the following specification:

$$
\pi_{t}-\pi_{e}=\alpha+\mathrm{A}(\mathrm{L})\left[\pi_{t}-\pi_{e}\right]+\mathrm{C}(\mathrm{L}) U_{t}+D_{1 t}+D_{2 t}+\mathrm{B}(\mathrm{L}) \varepsilon_{t}
$$

since the tests described above suggest the presence of structural breaks in the data, it was chosen to insert into the Equation (18) two dummies $\left(D_{1 t}\right.$ and

\footnotetext{
${ }^{7}$ The $\lambda$ parameter used was the recommended to quarterly data, that is, 1600 .
} 
$\left.D_{2 t}\right)$ in the regression with the aim of capturing the effects of these possible structural changes. The first dummy $\left(D_{1 t}\right)$ starts in 2004.Q1, while the second $\left(D_{2 t}\right)$, starts in 2015.Q1. However, the estimated residue of the Equation (18) equation may not necessarily be white noise, because inflation is not only determined by the unemployment rate. In this sense, it is necessary to determine the polynomial $\mathrm{B}(\mathrm{L})$, related to the residues. At this point, the best representation for the residues is an AR (1) model, so the equation to be estimated assumes the following specification:

Table 3: Results of NAIRU's coefficients estimation

\begin{tabular}{|c|c|c|c|c|c|c|c|c|}
\hline Variable & $c$ & $\mid\left[\pi_{t-1}-\pi_{t-1}\right.$ & $\left|\left[\pi_{t-2}-\pi_{t-2}\right]\right|$ & $U_{t}$ & $U_{t-1}$ & $D_{1 t}$ & $D_{2 t}$ & $\overline{\varepsilon_{t-1}}$ \\
\hline $\begin{array}{c}\pi_{t}-\pi_{e} \\
\text { Standard Error }\end{array}$ & $\begin{array}{l}0.6302 \\
0.1448\end{array} \mid$ & \begin{tabular}{|r|}
-2.1013 \\
0.6110
\end{tabular} & $\begin{array}{r}-0.6335 \\
0.1893\end{array}$ & $\begin{array}{r}-0.3218 \\
0.0816\end{array}$ & $\mid \begin{array}{r}-0.2390 \\
0.0960\end{array}$ & $\begin{array}{r}-0.8603 \\
0.1820\end{array}$ & $\begin{array}{r}-0.2245 \\
0.1270\end{array}$ & $\begin{array}{l}1.9662 \\
0.5624\end{array}$ \\
\hline $\begin{array}{c}J \text {-Test (Prob) } \\
\text { rank }\end{array}$ & \begin{tabular}{|c|}
0.8704 \\
19
\end{tabular} & & & & & & & \\
\hline
\end{tabular}

It is worth pointing out that according to the over-identification $J$ test, the instruments used are valid, given that it was not possible to reject the null hypothesis of joint validity of the instruments. Thus, admitting that NAIRU is nothing else than the unemployment rate where the current inflation equals the expected inflation, that is, $\left[\pi_{t}-\pi_{e}\right]=0$ and solving for $\mathrm{U}_{t} \forall t \in \mathrm{T}$, it is possible to obtain the NAIRU rate. 4 presents the estimated NAIRU's trajectory against unemployment rate.

Figure 4: Unemployment rate and NAIRU, 2000.Q1 a 2016.Q4

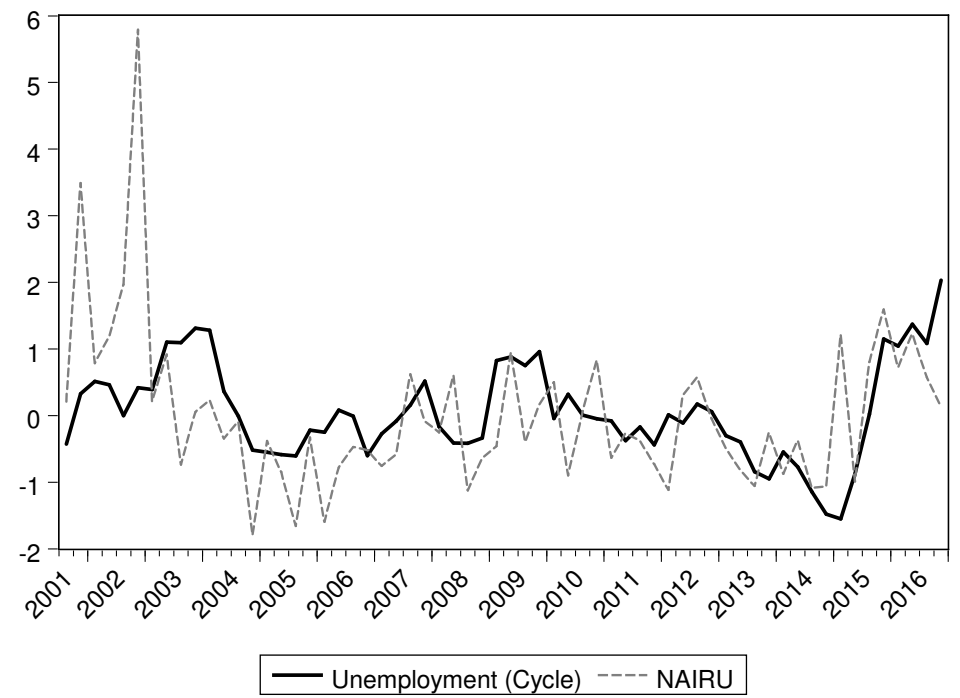

Source: Elaborated by the authors. 
The existing relationship between unemployment, NAIRU and inflation occurs as unemployment falls (rise) below (above) the NAIRU, leading to an acceleration (deceleration) in the inflation rate. In order to empirically test this relationship, it was estimated a simple regression among the variables, represented by:

$$
U_{t}-N A I R U_{t}=\beta_{0}+\beta_{1} \pi_{t}+\varepsilon_{t}
$$

The results of the estimate are expressed in Table 4 .

Table 4: Results of the estimation of Equation (19)

\begin{tabular}{cccc}
\hline $\mathrm{U}_{t}-\mathrm{NAIRU}_{t}$ & Coefficient & Standard Error & Prob. \\
\hline$c$ & 1.6522 & 0.1345 & 0.0000 \\
$\pi_{t}$ & -2.9198 & 0.2012 & 0.0000 \\
\hline $\mathrm{R}^{2}-$ Adjusted & 0.3865 & & \\
\hline \multicolumn{4}{c}{ Source: Elaborated by the authors. }
\end{tabular}

The negative and statistically different from zero coefficient implies that the estimated NAIRU rate is consistent for the Brazilian economy, because the theoretical relation provided by the Phillips curve is confirmed by the regression results through Robust Least Squares (Robust-LS).

\section{Results}

This section aims to present the estimate results of the New-Keynesian Phillips curve according to the described one in Equation (11) by means of a Markovswitching dynamic regression. The terms adopted in the estimation can be described as follows: as an endogenous variable, it was used the wage growth rate, $\pi_{t}^{w}$, the inflation series of IPCA was used as an independent variable, $\pi_{t}^{p}$, as well as the unemployment rate deviation relative to NAIRU (the latter estimated in subsection 4.3), $\hat{u}_{t}$. Preceding the dynamic model estimation, it is important to note that the number of Markovian regimes was fixed in two $(M=2)$ due to the number of observations (68 observations) avoiding then problems related to micronumerosity in the data. The results of the estimation are presented in Table 5.

According to the information specified in section 3, the angular coefficient $(\alpha)$ or the term referring to the intercept was defined as time invariant between the possible regimes, furthermore, it was statistically insignificant. The lagged price index $\left(\pi_{t-1}^{P}\right)$, different from that found in Oliveira \& Feijó (2015), was statistically equal to zero for the two regimes, pointing to the nonsignificance of the inflation rate of the previous period on the current rate of wages growth. In this sense, Campos et al. (2010), through the analysis of the impulse response function of a VAR model, reached the conclusion that there is no mechanism for transferring wage increases to prices in Brazil. This conclusion is motivated by the wage losses with the increase of unemployment, without counterpart in the inflationary process.

Another possible explanation is given by the higher importance of expectations about expected inflation to the detriment of lagged inflation for the Brazilian case. Junior \& Lima (2016), throughout a non-causal autoregressive model concluded that the inflationary expectations were the main factor 
Table 5: Estimation Results

\begin{tabular}{|c|c|c|}
\hline Coefficient & Regime 1 & Regime 2 \\
\hline$\alpha$ & \multicolumn{2}{|c|}{$\begin{array}{c}-2.9553 \\
(4.2871)\end{array}$} \\
\hline$\gamma \pi_{t-1}^{p}$ & $\begin{array}{l}6.5885 \\
(6.5000)\end{array}$ & $\begin{array}{c}12.3123 \\
(11.3341)\end{array}$ \\
\hline$\psi_{0} \hat{u}_{t}$ & $\begin{array}{c}2.8659^{*} \\
(1.2649)\end{array}$ & $\begin{array}{c}1.9444 \\
(5.0999)\end{array}$ \\
\hline$\psi_{1} \hat{u}_{t-1}$ & $\begin{array}{c}3.3375^{* *} \\
(1.9825)\end{array}$ & $\begin{array}{c}-7.7092^{* *} \\
(4.3630)\end{array}$ \\
\hline$\hat{\sigma}$ & $\begin{array}{r}1.9774^{*} \\
(0.3049)\end{array}$ & $\begin{array}{r}2.7262^{*} \\
(0.1680)\end{array}$ \\
\hline Log Likelihood & -237.3632 & \\
\hline
\end{tabular}

of Brazil's price formation process in the period between 1996 and 2014. In the same sense, Oliveira \& Feijó (2017) showed through an inverse quantile regression (IQR) the rising importance of the role played by expectations in the inflation process in Brazil, thus achieving one of the main goals of the Inflation Targeting Regime: the price formation anchored in the economic agents' expectations. According to Triches \& Feijó (2017), studies in this field of research have showed that the role played by the inflation expectation is relevant in inflation dynamics and the BACEN is reacting to changes in this variable. Thus, in the case inflation expectations is well anchored in inflation targeting or in any other macroeconomic indicator, the lagged inflation tends to present low persistence.

Regarding the variable that represents the unemployment rate deviation from the current natural unemployment level (NAIRU), one can observe that this variable plays a major role in determining wage growth. In the first regime, both the current unemployment deviation $\left(\hat{u}_{t}\right)$ and the lagged deviation $\left(\hat{u}_{t-1}\right)$ are significant, however, with signal contrary to the expected. This result suggests that in the periods when regime 1 is observed, the rise in the cyclical unemployment do not cause wage reductions. This behavior for the Phillips curve has already been investigated by Bacha \& Lima (2004), this author describes the joint move and positively related both the inflation and idle capacity (unemployment) to moments of adjustments, be it due to either economic or an institutional crisis. In this perspective, it is interesting to note that the regime 1 realization (5) can be associated to turbulent moments (with the exception of the period between 2004 and mid-2007) experienced in the Brazilian economy, such as the confidence crisis ${ }^{8}$ between the years of 2002 2003, as well as subprime crisis ${ }^{9}$ between $2009-2012$ and, lastly, the recent

\footnotetext{
${ }^{8}$ The so-called "crisis of confidence" comes from the fact that 2002 was marked by the election of a left-leaning political president (Luiz Inácio Lula da Silva), which generated a strong crisis of confidence regarding the orientation of policies of the new government, alerting international investors to the possibility of default of debt, reestablishment of companies, populist measures, among others.

${ }^{9}$ The subprime crisis triggered in 2008 due to subprime mortgage loans (subprime loan or subprime mortgage), a practice that culminated in several banks in a situation of insolvency, impacting the stock markets around the world
} 
economic-political crises experienced by Brazil from 2013 to the present day.

A possible explanation for such fact resides in the loss of credibility in financial institutions during crisis periods to control inflation. The work of Mendonça \& Santos (2006) emphasizes the importance of monetary policy credibility in the Brazilian Phillips curve prediction in the period after the adoption of the inflation targeting. On the one hand, studies such as Santos (2014) and Sachsida et al. (2009) attributes to unemployment low representatibility in the Phillips curve for Brazil, the latter paper, e.g, points out for the non-existence of the trade-off between inflation and unemployment in Brazil, not even in the short-run.

Another explanation for the Phillips curve behavior at regime 1 is ruled by the production factors productivity, in this sense, Campos et al. (2010) argues that the productivity advance, instead of raising wage without causing inflation (as suggested by microeconomics), reduces wage and raises unemployment. In this context, the authors argue that the influence of productivity on wage may explain to some extent the reason why when there is a process of wage reduction this is not passed on to the inflationary process, thus, the firms markup fluctuations would absorb wage fluctuations, preventing the Phillips curve mechanism from operating fully in Brazil.

On the one hand, in the second regime, the current cyclical unemployment $\left(\hat{u}_{t}\right)$ lost its statistical significance, while the lagged unemployment $\left(\hat{u}_{t-1}\right)$ shows up both a signal reversion and a raise in its coefficient value, which became twice the regime 1 . This behavior suggests a delay in wage response due to changes in the unemployment rate as result of a possible degree of rigidity in the relationship between these variables. Furthermore, as mentioned in Donayre \& Panovska (2016) slow responses of wage due to changes in unemployment may also be a sign of an asymmetric response in the aftermath of turbulent periods, as it seems to be the case for the regime 2. In this case, where the regime 2 is realized, it is possible to observe that a raise in unemployment causes wage deflation, in the sense of remuneration reduction, which is in consonance with the economic theory proposed in Phillips (1958). This Phillips curve behavior refers to either economic periods of "heating" or "cooling" and in the Brazilian context it is also associated to economic stable moments, as it can be seen in (5).

Lastly, it is possible to observe that the variance is different between regimes, being higher in the regime 2 . Together, these facts suggest that the sole responsible for the variability of wage growth, between regimes, is the unemployment rate. In the first regime, the Phillips curve is not validated, that is, there is no trade-off between inflation and unemployment, according to Phillips (1958). Contrary to what was expected, there is a positive relationship between unemployment and wage growth which refers either to economic or institutional unstable periods, according to Bacha \& Lima (2004). On the other hand, the second regime is characterized for the existence of the negative relation between unemployment and wage inflation. A possible explanation for the different scenarios in the variance variability between regimes resides in the change of orientation of the institutional apparatus in Brazil, mainly regarding to the abandonment of the "macroeconomic tripod". Recently, this discusion was estimulated for Pastore et al. (2014) and Nobrega et al. (2020).

The 5 shows both filtered and smoothed models probability. From the graphs, it is possible to observe that there is no distinction among dominant regimes for a long period of time, that is, one may verify an alternation be- 
tween regimes.

Figure 5: Probabilities of transition of the model

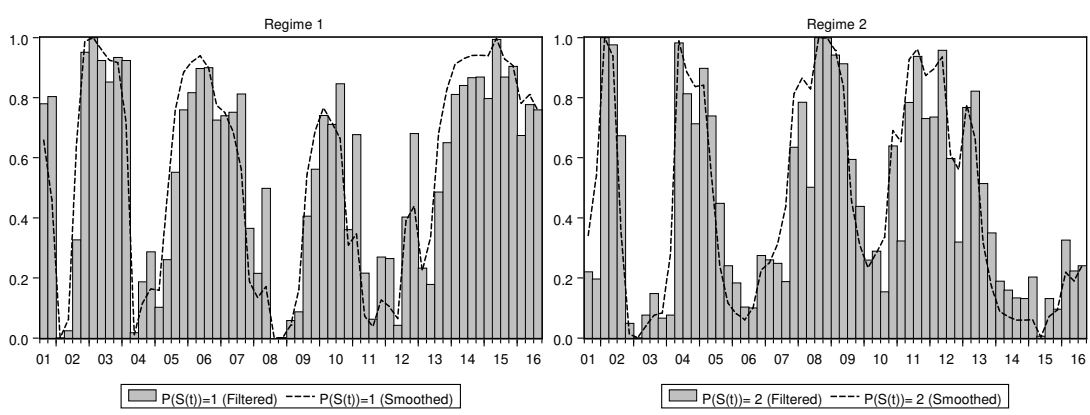

Source: Elaborated by the authors.

[1] Note: The bars displays the filtered transition probability, while the dashed lines show the smoothed transition probability.

However, a look in the most recent period shows that raise in the unemployment rate may be associated to the prevalence of regime 1 , in which the Phillips curve is not validated for the empirical model. As aforementioned, it is important to highlight the realization of regime 1 in turbulent periods for the Brazilian economy, while the regime's 2 prevailing may be associated to stable periods.

Proceeding to the analysis of the dynamic model results, Table 6 presents both the matrix of transition probabilities and the expected duration of the regimes of the model. It is possible to notice that both regimes are iterates, given that there is high persistence for the economy state at any regime. In other words, when the Phillips curve classic hypothesis is not validated (regime 1 ), the probability of staying in this regime is of $83.48 \%$, while the probability of change for the economy state where the trade-off between unemployment and inflation is validated (regime 2 ) is of $16.52 \%$.

Table 6: Matrix of Probability of Transition and Expected Duration

\begin{tabular}{ccc}
\hline Transition & Regime 1 & Regime 2 \\
\hline Regime 1 & $83.48 \%$ & $16.52 \%$ \\
Regime 2 & $20.60 \%$ & $79.40 \%$ \\
\hline Duration & 6.0551 & 4.8558 \\
\hline
\end{tabular}

Source: Elaborated by the authors.

The same reasoning can be applied to the regime 2. Under this scheme, the probability of permanence is $79.40 \%$, while the probability of switching to regime 1 is approximately $20.60 \%$. The third line of Table 6 shows the expected duration of the regimes, for the first regime there is an expected average duration of approximately 6 periods (quarters), while the second regime presents an average expected duration of approximately 5 periods. 


\section{Concluding Remarks}

Motivated by the acceleration observed in the unemployment rate in the last few years, the present research sought to investigate the relationship between inflation in wage and unemployment, as originally proposed by Phillips (1958), in order to identify the possible causes of the reversal in the trend of the unemployment in Brazil. The empirical strategy adopted followed the specification of the Phillips curve proposed by Gali (2011), estimated through the Markovswitching regression model developed by Hamilton (1989).

In relation to the NAIRU rate, as in Oliveira et al. (2016), the estimation was performed through the transfer equation, because it is an unobserved component. Thus, the estimated NAIRU proved to be consistent with economic theory, which was evidenced by the result of the estimation of a simple equation relating the unemployment deviation from the natural rate and the current inflation.

The results of the regression model with Markovian change suggest that the relationship between wage and unemployment occurs in two distinct and well-defined ways. On the one hand, there are periods of non-validation of the relation of Phillips (1958), while on the other hand, this relation is validated. In relation to the transition between states, it is worth emphasizing the importance of the economic cycle on the realization of the different Markovian regimes. This result is in line with other studies using the Markovian model approach, such as Oliveira \& Feijó (2015), in which these authors identified different regimes with characteristics similar to those found in the present study, that is, validation periods interspersed with periods of non-validation of the Phillips curve.

The main contribution of this work is the identification of different states of intensity in the interaction between wage and unemployment, which may contribute to policy makers by stimulating the debate about the asymmetries in the response of employment policies to the dynamics of inflation in the Brazilian context.

As a suggestion for future research, it is interesting to note that asymmetries and different regimes in the wage-unemployment relationship deserve a more detailed investigation in a regional context, since it is plausible that there are also asymmetries at the local level, given the heterogeneity in the income dynamics and employment among the states of Brazil, focusing on the characteristic of the productive dynamism of each region. In addition, asymmetries related to the economic cycle, as identified in the present research, may compromise (or boost) local employment policies if carried out at inappropriate times.

\section{Acknowledgement}

This study was financed in part by the Coordenação de Aperfeiçoamento de Pessoal de Nível Superior - Brasil (CAPES) - Finance Code 001.

\section{References}

Aragon, E. K. D. S. B., De Medeiros, G. B., Portugal, M. S. \& Others (2016), Instabilidades na Curva de Phillips Novo-Keynesiana: Um Estudo Empírico 
para o Brasil, in 'Anais do XLIII Encontro Nacional de Economia [Proceedings of the 43rd Brazilian Economics Meeting]', ANPEC - Associação Nacional dos Centros de Pós-Graduação em Economia, p. 20.

Bacha, C. J. C. \& Lima, R. A. S. (2004). A Curva De Phillips e a Economia Brasileira: Período de 1991 a 2002. Pesquisa e Debate, v. 15, n. 25, p. 131-162.

Bonelli, R. \& Veloso, F. A. (2014), Panorama do mercado de trabalho no Brasil, Editora FGV.

Calvo, G. A. (1983). Staggered prices in a utility-maximizing framework. Journal of monetary Economics, Elsevier, v. 12, n. 3, p. 383-398.

Campos, M. J. C., Lima, R. C. \& Campos, L. H. R. (2010). Investigação sobre o relacionamento do Desemprego, dos salários e da inflação no Brasil pósreal. Economia e Desenvolvimento, v. 9, p. 109-148.

Dickey, D. A. \& Fuller, W. A. (1979). Distribution of the Estimators for Autoregressive Time Series With a Unit Root. Journal of the American Statistical Association, v. 74, n. 366, p. 427, jun. DOI: 10.2307/2286348. Disponível em: https://www.jstor.org/stable/2286348?origin=crossref.

Donayre, L. \& Panovska, I. (2016). Nonlinearities in the U.S. wage Phillips curve. Journal of Macroeconomics, Elsevier Inc., v. 48, p. 19-43, jun. DOI: 10.1016/j.jmacro.2016.01.004. Disponível em: http://dx.doi.org/10.1016/j.jmacro.2016.01.004 https://linkinghub.elsevier.com/retrieve/pii/S0164070416000057.

Enders, W. (2008), Applied econometric time series, John Wiley \& Sons.

Erceg, C. J., Henderson, D. W. \& Levin, A. T. (2000). Optimal monetary policy with staggered wage and price contracts. Journal of monetary Economics, Elsevier, v. 46, n. 2, p. 281-313.

Friedman, M. (1977). Nobel Lecture: Inflation and Unemployment. Journal of Political Economy, v. 85, n. 3, p. 451-472, jun. DOI: 10.1086/260579. Disponível em: https://www.journals.uchicago.edu/doi/10.1086/260579.

Galí, J. (2011). The Return of the Wage Phillips Curve. Journal of the European Economic Association, v. 9, n. 3, p. 436-461. DOI: 10.1111/j.15424774.2011.01023.x.

Garton, P. \& Others (2008), The resources boom and the two-speed economy, Technical Report 3, Commonwealth of Australia. Department of the Treasury.

Hamilton, J. D. (1989). A New Approach to the Economic Analysis of Nonstationary Time Series and the Business Cycle. Econometrica, v. 57, n. 2, p. 357-384.

Junior, R. L. B. \& Lima, E. C. R. (2016), Estimativas da Curva de Phillips Novo Keynesiana Para o Brasil: Uma Abordagem Via Autorregressão Não Causal, in 'Anais do XLIV Encontro Nacional de Economia [Proceedings of the 44rd Brazilian Economics Meeting]', ANPEC - Associação Nacional dos Centros de Pós-Graduação em Economia, p. 20.

URL: https://econpapers.repec.org/RePEc:anp:en 2016:42 
Kwiatkowski, D., Phillips, P. C. B., Schmidt, P. \& Shin, Y. (1992). Testing the null hypothesis of stationarity against the alternative of a unit root: How sure are we that economic time series have a unit root?. Journal of econometrics, Elsevier, v. 54, n. 1-3, p. 159-178.

Lee, J. \& Strazicich, M. C. (2003). Minimum Lagrange Multiplier Unit Root Test with Two Structural Breaks. The Review of Economics and Statistics, v. 85, n. 4, p. 1082-1089.

Lee, J. \& Strazicich, M. C. (2013). Minimum LM Unit Root Test With One Structural Break. Economics Bulletin, v. 33, p. 2483-2492.

Mendonça, H. F. \& Santos, M. A. L. (2006). Credibilidade da Política Monetária e a Previsão do Trade-off entre Inflação e Desemprego - Uma Aplicacão para o Brasil. Revista Economia, v. 7, n. 2, p. 293-306.

Mendonça, M. J. C., Sachsida, A. \& Medrano, L. A. T. (2012). Inflação versus desemprego: novas evidências para o Brasil. Economia Aplicada, v. 16, n. 3, p. 475-500, sep. DOI: 10.1590/S1413-80502012000300006. Disponível em: http://www.scielo.br/scielo.php?script=sci_arttext\&pid=S1413$80502012000300006 \& \operatorname{lng}=$ pt\&nrm=iso\&tlng=en.

Nobrega, W. C. L., Maia, S. F. \& Besarria, C. N. (2020). Interação entre as políticas fiscal e monetária: uma análise sobre o regime de dominância vigente na economia brasileira. Análise Econômica, Universidade Federal da Paraíba, v. 38, n. 75, p. 7-36, apr. DOI: 10.22456/2176-5456.71935. Disponível em: http:// tede.biblioteca.ufpb.br/handle/tede/8684 https://seer.ufrgs.br/ AnaliseEconomica/article/view/71935.

Oliveira, L. D. \& Feijó, F. T. (2015), Curva de Phillips com mudança de regime markoviano: Uma análise da economia brasileira para o período de 1995-2014, in 'Anais do XLIII Encontro Nacional de Economia da ANPEC [Pro-ceedings of the 43rd Brazilian Economics Meeting]', ANPECAssociação Na-cional dos Centros de Pós-Graduação em Economia., p. 25.

Oliveira, L. D. \& Feijó, F. T. (2017), Expectativas Passadas ou Futuras? Uma Análise do Processo Inflacionário Brasileiro Recente a partir da Regressão Quantílica Inversa, Technical report, ANPEC- Associação Nacional dos Centros de Pós-Graduação em Economia., Natal-RN.

Oliveira, L., Portugal, M. S. \& Abrita, M. B. (2016). Taxa de Desem-prego Não Aceleradora da Inflação: Uma estimação da NAIRU para a economia brasileira no período de 2000 até 2013. Nova Economia, v. 26, n. 2, p. 491513, aug. DOI: 10.1590/0103-6351/2585. Disponível em: http:// www.scielo.br/scielo.php?

script=sci_arttext\&pid=S0103-63512016000200491\&lng=pt\&tlng=pt.

Pastore, A., Gazzano, M. \& Pinotti, M. (2014), Inflação e Crises: O Papel da Moeda., 1 edn, Elsevier Brasil.

Perron, P. (1990). Testing With a a Root Mean in a Time Series Changing. Journal of Business $\mathcal{E}$ Economic Statistics, v. 8, n. 2, p. 153-162. 
Phillips, A. W. (1958). The Relation Between Unemployment and the Rate of Change of Money Wage Rates in the United Kingdom, 1861?1957. Economica, v. 25, n. 100, p. 283-299, nov. DOI: 10.1111/j.1468-0335.1958.tb00003.x Disponível em: http://doi.wiley.com/10.1111/j.1468-0335.1958.tb00003.x.

Phillips, P. C. B. \& Perron, P. (1988). Testing for a unit root in time series regression. Biométrika, v. 75, n. 2, p. 335-346. DOI: 10.1093/biomet/75.2.335.

Portugal, M. S. \& Madalozzo, R. C. (2000). Um modelo de NAIRU para o Brasil. Revista de economia política (São Paulo), v. 20, n. 4, p. 26-47.

Sachsida, A., Ribeiro, M. \& dos Santos, C. H. (2009), A curva de Phillips e a experiência brasileira, in 'Texto para Discussão, No. 1429', Institute of Applied Economic Research (IPEA), Brasília, p. 40.

URL: http://repositorio.ipea.gov.br/handle/11058/2567

Santos, F. S. D. (2014), Ascensão e Queda do Desemprego no Brasil: 19982012, in 'Anais do XLI Encontro Nacional de Economia [Proceedings of the 41rd Brazilian Economics Meeting]', ANPEC - Associação Nacional dos Centros de Pós-Graduação em Economia, p. 20.

URL: https://econpapers.repec.org/RePEc:anp:en 2013:232

Schwartzman, F. F. (2006). Estimativa de curva de Phillips para o Brasil com preços desagregados. Economia Aplicada, SciELO Brasil, v. 10, n. 1, p. 137155.

Triches, D. \& Feijó, F. T. (2017). An estimation of the hybrid Phillips curve for Brazil in the inflation targeting regime. Economia Aplicada, v. 21, n. 1, p. 29, apr. DOI: 10.11606/1413-8050/ea150953. Disponível em: https://www.revistas.usp.br/ecoa/article/view/135130.

Zivot, E. \& Andrews, D. W. K. (1992). Further Evidence on the Great Crash, the Oil-Price Shock, and the Unit-Root Hypothesis. Journal of Business E Economic Statistics, v. 10, n. 3, p. 251-270. DOI: 10.1198/073500102753410372. 


\section{Appendix A - Time series}

Table A.1: Description of the variables

\begin{tabular}{l|c|c|c}
\hline \multicolumn{1}{c|}{ Serie } & Variable & Source & $\begin{array}{c}\text { Code } \\
\text { (SGS) }\end{array}$ \\
\hline $\begin{array}{l}\text { National Price Index } \\
\text { to the Broad Consumer (IPCA) }\end{array}$ & Inflation & IBGE & 433 \\
$\begin{array}{l}\text { National Price Index } \\
\text { to the Consumer (INPC) }\end{array}$ & Inflation & IBGE & 188 \\
$\begin{array}{l}\text { Unemployment Rate in the Metropolitan } \\
\begin{array}{l}\text { Region of Sao Paulo } \\
\text { Remuneration of } \\
\text { Employees (Revenue) }\end{array}\end{array}$ & Unemployment & Seade/PED & - \\
\hline
\end{tabular}

Source: Elaborated by the authors.

Figure A.1: Temporal trajectory of the variables
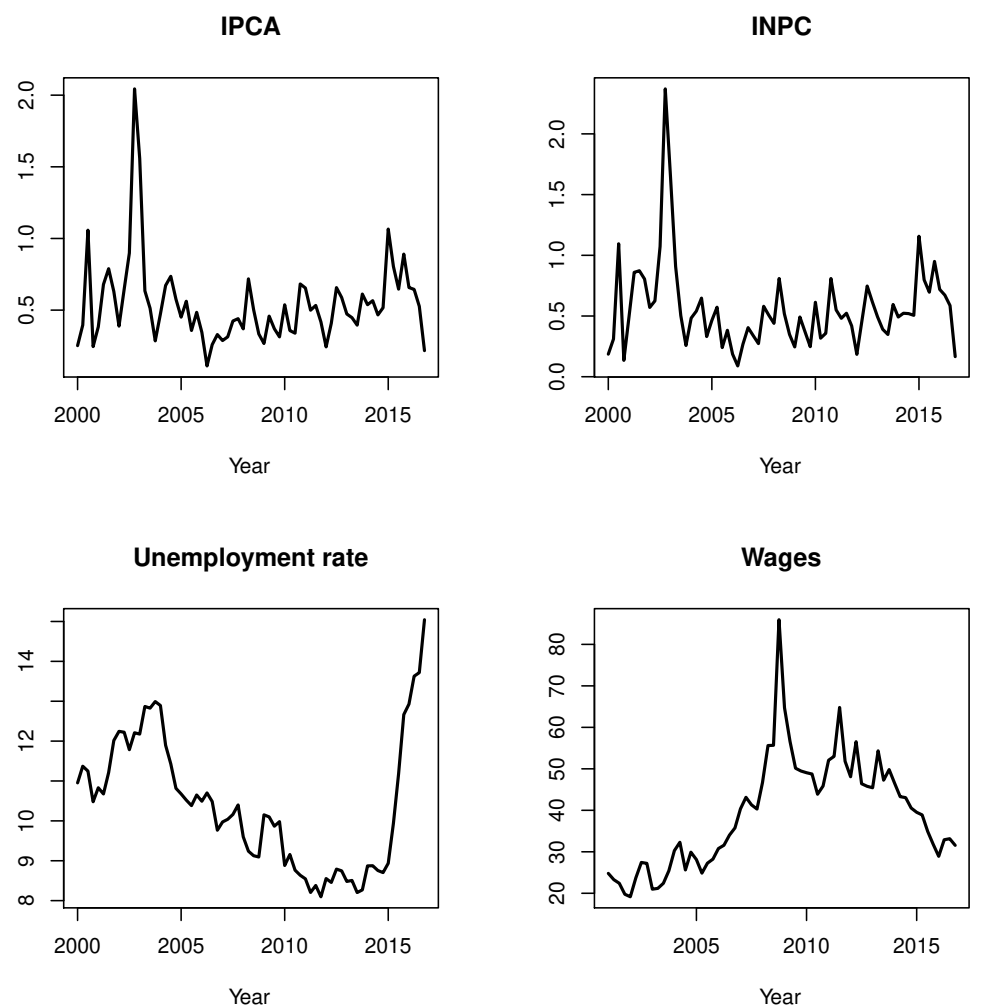

Source: Elaborated by the authors.

[1] Note: Elaborated in the software R-Studio. 


\section{Appendix B - Econometric tests}

Figure B.1: Unemployment correlogram

\section{Sample: 2001Q3 2016Q4 \\ Included observations: 57}

\begin{tabular}{l|lllllll}
\hline \hline Autocorrelation & Partial Correlation & AC & PAC & Q-Stat & Prob \\
\hline \hline & & &
\end{tabular}

Source: Elaborated by the authors.

[1] Note: Elaborated in the software Eviews.

Table B.1: Conventional unit root tests

\begin{tabular}{cccrccc}
\hline Variable & $\begin{array}{c}\text { t-value } \\
\text { ADF }\end{array}$ & $\begin{array}{c}\text { Critical Value } \\
\text { ADF }\end{array}$ & $\begin{array}{c}\text { t-value } \\
\text { PP }\end{array}$ & $\begin{array}{c}\text { Critical Value } \\
\text { PP }\end{array}$ & $\begin{array}{c}\text { t-value } \\
\text { KPSS }\end{array}$ & $\begin{array}{c}\text { Critical Value } \\
\text { KPSS }\end{array}$ \\
\hline IPCA & -4.737 & -3.45 & -4.453 & -3.477 & 0.112 & 0.146 \\
SIPCA & -8.273 & -3.45 & -10.899 & -3.478 & 0.09 & 0.146 \\
INPC & -4.382 & -3.45 & -4.462 & -3.477 & 0.104 & 0.146 \\
SINPC & -8.150 & -3.45 & -11.117 & -3.478 & 0.085 & 0.146 \\
U & 1.066 & -3.45 & 0.899 & -3.477 & 0.139 & 0.146 \\
UU & -3.734 & -3.45 & -6.610 & -3.478 & 0.157 & 0.146 \\
W & -1.442 & -3.45 & -1.862 & -3.481 & 0.163 & 0.146 \\
$\Delta \mathrm{W}$ & -6.381 & -3.45 & -9.854 & -3.484 & 0.121 & 0.146 \\
\hline
\end{tabular}

Source: Elaborated by the authors.

[1] Note: Elaborated in the software R-Studio. 
Table B.2: Structural break unit root tests

\begin{tabular}{|c|c|c|c|c|c|c|}
\hline \multirow{2}{*}{ Variable } & \multicolumn{2}{|c|}{ Zivot-Andrews } & \multicolumn{2}{|c|}{ Lee-Strazicich (2013) } & \multicolumn{2}{|c|}{ Lee-Strazicich $(2003)$} \\
\hline & ZA & Break & \begin{tabular}{|c} 
LM \\
$(1$ break $)$
\end{tabular} & Break & \begin{tabular}{|c|} 
LM \\
(2 breaks)
\end{tabular} & Breaks \\
\hline INPC & -4.59722 & 2003Q2 & -5.2882 & 2003Q3 & -6.8753 & $\begin{array}{c}D_{1 t}: 2003 \mathrm{Q} 1 \\
D_{2 t}: 2015 \mathrm{Q} 1\end{array}$ \\
\hline IPCA & -4.50609 & 2003Q3 & -5.1368 & 2003Q3 & -6.0489 & $\begin{array}{c}D_{1 t}: 2003 \mathrm{Q} 2 \\
D_{2 t}: 2014 \mathrm{Q} 3\end{array}$ \\
\hline $\mathrm{U}$ & -1.72625 & 2014Q3 & -2.2802 & 2013Q3 & -4.3904 & $\begin{array}{c}D_{1 t}: 2004 \mathrm{Q} 1 \\
D_{2 t}: 2014 \mathrm{Q} 2\end{array}$ \\
\hline $\mathrm{W}$ & -2.80673 & 2006Q4 & -5.1146 & 2008Q1 & -5.6853 & $\begin{array}{c}D_{1 t}: 2007 \mathrm{Q} 3 \\
D_{2 t}: 2009 \mathrm{Q} 1\end{array}$ \\
\hline
\end{tabular}

Source: Elaborated by the authors.

[1] Zivot \& Andrews (1992) test: Model with intercept and trend - critical t $(1 \%=-5.57,5 \%=-5.08,10 \%=-4.82)$.

[2] Lee \& Strazicich (2003) and Lee \& Strazicich (2013) unit root tests were performed in the software RATS.

[3] Lee \& Strazicich (2003) and Lee \& Strazicich (2013) tests: Model C: with intercept and trend - critical t $(1 \%=-5.05 /-5.11,5 \%=-4.45 /-4.51$,

$10 \%=-4.17 /-4.21)$. 
